\title{
Evaluation and Management of Neonates with Possible Congenital Zika Virus Infection
}

\author{
Ki Wook Yun, M.D.
}

Division of Infectious Diseases, Department of Pediatrics, Seoul National University College of Medicine, Seoul, Korea

\section{ABSTRACT}

Zika virus infection is, typically, either asymptomatic or causes mild illness; however, it may present severe clinical manifestations in neonates. Zika virus can be transmitted from a pregnant woman to her fetus, subsequently causing microcephaly and serious brain anomalies. Recently, the full spectrum of anomalies in neonates congenitally infected by Zika virus has been delineated as congenital Zika syndrome. Five major features are unique to congenital Zika syndrome: severe microcephaly with a partially collapsed skull, thin cerebral cortices with subcortical calcifications, macular scarring and focal pigment mottling of the retina, congenital contractures, and extrapyramidal symptoms. Recognition of this phenotype in neonates and infants by clinicians can help ensure appropriate etiologic evaluation of Zika virus infection and determine the required duration of follow-up and clinical care. Neonates with congenital Zika virus infection should be evaluated by a team of multiple specialists within the first year of life; the evaluations should include assessments of vision, hearing, feeding, growth, and neurodevelopmental function. Moreover, it is recommended that infants who show laboratory evidence of congenital Zika virus infection without apparent abnormalities be continuously monitored and screened by the primary care provider; repeated hearing tests should be carried out for such infants.

Key Words: Zika virus, Congenital Zika syndrome, Mosquitoes, Microcephaly, Neonates

\section{서론}

2015년 봄부터 브라질에서 시작된 지카바이러스(Zika virus)의 대규모 유행은 현재까지도 전 세계적으로 큰 관심을 받고 있다 ${ }^{1)}$. 특히 선천감염으로 인해 태아에게 소두증을 비롯한 심각한 중추신경계 합병증을 일으킬 수 있는 것으로 알려지면서 산부인과 및 소아청소년과 의사들에게 더욱 중요한 질환으로 인식되고 있달. 아직 국내 자체 발병사례는 없으며, 해외 유입례에서도 임신부 감염은 없었기에 실질적인 큰 위험으로 인식되고 있지는 않으나, 특히 우리나라 여행객 이 많은 동남아시아의 여러 휴양지로부터 감염례가 늘고 있고 ${ }^{3)}$, 온난화와 함께 매개 모기의 서 식지 변화로 인해 우리나라에서도 자체 감염이 발생할 가능성이 열려 있어, 지카바이러스 선천
Received: 13 July 2017

Accepted: 28 July 2017

Correspondence to: Ki Wook Yun

Department of Pediatrics, Seoul

National University Children's

Hospital Pediatrics, 101 Daehak-ro, Jongno-gu, Seoul 03080, Korea

Tel: +82-2-2072-4909

Fax: +82-2-743-3455

E-mail: pedwilly@gmail.com

Copyright(c)

By Korean Society of Neonatology.

All right reserved.

This is an Open-Access article distributed under the terms of the Creative Commons Attribution Non-Commercial License (http://creativecommons.org/licenses/ by-nc/4.0), which permits unrestricted non-commercial use, distribution, and reproduction in any medium, provided the original work is properly cited. 
감염이 의심되는 신생아의 진단 및 관리에 대한 최신 지견을 관련 전 문가들이 숙지할 필요가 있다. 본 종설은 현재까지 알려진 지카바이 러스 관련 역학 및 임상적 특징을 정리하고, 지카바이러스 선천 감염 의 진단 및 관리의 주요 권고안들을 소개하고자 한다.

\section{지카바이러스의 특징}

\section{1. 바이러스학적 측면}

파리, 모기, 진드기 등 흡혈하는 절지동물에 의해서 사람을 비롯 한 각종 척추동물로 전파되는 바이러스들을 arbovirus (arthropodborne virus)라고 칭한다. Arbovirus에는 4 개의 family, 즉 Bunyaviridae, Flaviviriae, Reoviridae, Togaviridae가 포함되어 있고, 여기 에 다시 수십 종의 바이러스들이 속해 있다. 이들 arbovirus들은 세 계 각지에서 주로 동물에게 감염을 일으키는데, 그 중 특히 인체 감 염을 일으키는 바이러스들로서 Flaviviriade family의 flaviviruses genus에 속한 황열바이러스(Yellow fever virus), 뎅기바이러스 (Dengue virus), 일본뇌염바이러스(Japanese encephalitis virus, JEV), 지카바이러스와 Togaviridae family의 alphaviruses genus에 속한 치쿤구니야 바이러스(Chikungunya virus)가 있다(Table 1). 이 들에 의한 인체 감염은 모두 모기에 의해 매개되며, 감염 시 주로 발 열-발진성 질환을 일으키고 신경계 합병증까지 초래할 수 있다. 아 프리카와 남미, 동남아시아 등 열대 지방에서 주로 유행하지만, 우 리나라에서도 일본뇌염바이러스는 계속 문제가 되고 있다 ${ }^{4)}$.

\section{2. 역학적 측면}

대부분의 arbovirus들은 동물-모기-동물로 이어지는 생활사를 가 지며, 사람을 비롯한 척추동물은 바이러스를 보유한 모기에 물려 우 연히 감염된다. 바이러스가 인체 내로 유입된 후 발생하는 바이러스 혈증은 그 정도가 약하고 기간이 짧아서, 다시 매개 모기에 물림으로 써 그 모기를 감염시키고 이것이 다시 다른 사람에게 바이러스를 전 파시키는 것은 거의 불가능한 것으로 알려져 있다. 그러나, 앞서 주 로 인체 감염을 일으키는 것으로 소개한 황열바이러스, 뎅기바이러 스, 치쿤구니야 바이러스, 지카바이러스는 이러한 감염 방식이 비교 적 흔하게 일어나고, 따라서 감염자들이 모기에 노출되는 것이 지역

Table 1. Classification of Arboviruses

\begin{tabular}{ll}
\hline Family & Genus (main species in human) \\
\hline $\begin{array}{l}\text { Bunyaviridae } \\
\text { Flaviviridae }\end{array}$ & $\begin{array}{c}\text { Nairoviruses, Orthobunyaviruses, Phleboviruses } \\
\text { Flaviviruses (Japanese encephalitis virus, Yellow } \\
\text { fever virus, Dengue virus, Zika virus) }\end{array}$ \\
Reoviridae & Coltiviruses, Orbiviruses, Seadornaviruses \\
Togaviridae & Alphaviruses (Chikungunya virus)
\end{tabular}

사회의 바이러스 전파에 큰 역할을 한다 ${ }^{4,5)}$. 바이러스혈증 상태의 숙 주를 모기가 흡혈해서 바이러스가 모기 내로 들어오면 서서히 장으 로 이행한 후 충분히 증식을 하고, 이후 다시 침샘으로 이행해서 잠 복해 있다가 모기가 다른 숙주를 흡혈할 때 침을 따라 숙주에게 전 파된다. 이렇게 모기 안에서 바이러스가 장에서 증식된 후 침샘으로 모일 때까지 대개 10 일 정도의 시간이 소요된다고 알려져 있고, 이 시기를 모기-매개 바이러스의 외잠복기(extrinsic incubation period) 라고 한다. 바이러스는 모기 안에서 약 15일간 증식한 후 1-2개월 최 대치로 유지된다 ${ }^{6)}$.

지카바이러스 감염은 수혈, 성접촉, 경태반, 모유 수유로도 가능 하나, 가장 흔하고 중요한 방식은 앞서 언급한 대로 매개 모기에 의 한 감염이다. 우리나라에서 주로 서식하면서 일본뇌염바이러스를 매개하는 Culex 모기와는 다른 Aedes, 일명 숲모기가 지카바이러스 는 물론 뎅기바이러스와 치쿤구니야 바이러스를 함께 매개하고 있 다. 그 중에서도 이집트 숲모기(A. aeqypti)는 주로 열대/아열대 지 역에 광범위하게 서식하면서 현재 지카바이러스의 대유행을 주도하 고 있다. 이 모기의 서식지가 다행히 위도상 우리나라 제주도 이남 으로 한정되어 있어 우리나라와 일본, 미국 등 온대 지역에서는 자 체 발생례가 거의 없으나, 온난화가 지속되어 평균 기온이 상승하면 모기 서식지의 위도가 높아지게 되고, 국내에서도 이런 모기에 의한 지카바이러스의 감염이 자체 발생할 가능성이 있다 ${ }^{5,7)}$. 한편, 이집트 숲모기 외에 흰 줄 솦모기(A. albopictus)도 지카바이러스 감염을 매 개할 수 있는 것으로 알려져 있는데, 이 모기는 우리나라와 일본을 비롯해서 온대 지역에서도 많이 서식하고 있고, 세계적으로 그 유입 사례가 증가하는 추세여서 관심을 받고 있다. 따라서 현재 우리나라 에서는 여름철 흰 줄 숲모기의 활동 및 모기 내 바이러스 유무를 감 시하고 있으며, 국내 자체 지카바이러스감염이 발생한다면 이 흰 줄 솦모기에 의해서일 것으로 예상하고 있다 ${ }^{8,9)}$.

\section{3. 임상적 측면}

감염환자에서 임상증상은 대개 경미하다. 모기에 물리거나 성접 촉 등으로 바이러스가 체내에 들어오면 2-14일의 잠복기를 거친 후 약 $30 \%$ 정도에서만 증상이 발현하는 것으로 알려져 있다. 증상은 발 열, 발진, 관절통, 결막염 등의 비특이적 바이러스 감염증의 양상이 며, 3-7일 지속 후 자연 소실된다 ${ }^{10,11)}$. 그러나 이러한 증상 발현 이후 일부에서 Guillain-Barré syndrome이 발생하고, 특히 선천 감염 시 소두증(microcephaly) 등의 신경계 합병증을 초래할 수 있기 때문에 중요한 질환으로 인식되고 있다 ${ }^{12,13)}$.

지카바이러스 선천감염으로 인한 소두증의 발생은 2015년 브라 질의 산부인과 의사인 Dr. Melo에 의해 처음 보고되었다 ${ }^{2)}$. 뇌 내 석 회화(intracranial calcification)와 뇌실 확장(enlarged brain's inner chambers)을 동반하는 비전형적인 양상의 선천성 뇌 기형의 태아 초음파 소견을 반복적으로 경험하면서 이를 보건 당국에 보고하였 
고, 2015년 11월 관계 당국은 이것을 국가적인 위험 상황으로 선포하 였다 ${ }^{14)}$. 2015년 한 해 동안 브라질에서의 소두증 발생은 예년에 비해 20배 증가하였고, 2016년 10월까지 공식 집계된 자료에서는 지카바 이러스와의 관련성이 확인된 소두증이 2,000례 이상, 관련성이 의심 되어 확인 중인 소두증이 3,000례 이상 있었고, 사망률은 8-10\%였다 15). 미국에서도 주로 남미 여행 후 지카바이러스 감염이 의심되는 임 신부의 수가 꾸준히 증가하고 있으며, 이들 중 약 $5 \%$ 의 태아에서 뇌 기형이 확인된 바 있다. 지카바이러스가 확인된 임신부 중에서는 10 $\%$, 그 중 특히 임신 1 기에 감염된 경우에는 $15 \%$ 에서 태아로부터 뇌 기형을 확인할 수 있었다 ${ }^{16}$. 이렇듯 지카바이러스와 뇌기형의 연관 성은 그간 많은 역학 연구들을 통해 꾸준히 제기되었으나, 결정적으 로 2016년 Rasmussen 등에 의한 연구에서 기형유발원과 특정 질환 과의 인과관계를 증명하는 Shepard's criteria와 Bradford Hill criteria 를 지카바이러스에 적용함으로써, 그 인과관계를 증명하였다 ${ }^{13}$.

\section{현재까지의 역학}

우간다(Uganda)의 지카숲(Zika forest)에서 1947년에 처음으로 발견된 이후, 주로 아시아와 아프리카에서 지카바이러스의 산발적 인 인체 감염례가 있었다 ${ }^{10)}$. 2007년 4월에는 남태평양의 Yap섬에서 처음으로 비교적 큰 규모의 유행이 발생하면서 4 개월여간 49 명의 확진자와 59명의 추정감염자가 나왔다. 이후 혈청학적 연구를 통해 서 이 지역 인구의 $3 / 4$ 이 당시 감염되었음을 보고하였다 ${ }^{17}$. 2013년 에는 역시 남태평양에 위치한 프랑스령 폴리네시아에서 지카바이러 스의 대규모 유행이 발생하여 10 주간 294 명의 확진자를 보고하였다 18) 연이어 2014년과 2015년에 남태평양의 다른 섬들로 지카바이러 스 유행이 이어지다가 결국 2015년 5월에 브라질에서 첫 지카바이 러스 인체 감염례가 나왔다. 이후로 브라질을 중심으로 남미 전역에 지카바이러스의 대규모 유행이 진행되었으며, 2016년 3월까지 브라 질에서만 50-150만명, 콜롬비아에서는 4만명 이상이 감염된 것으로 추정되었다. 2017년 5월 24일 기준 총 78개국이 최근 2개월 이내에 환자가 발생하여 여행 위험국으로 지정 되었으며, 주로 중남미에 집 중되어 있고(48개국), 아시아에서도 태국, 필리핀, 베트남 등 11 개국 이 포함되어 있다 ${ }^{19,20)}$.

국내에서 자체 발생례는 없으며, 해외 유입 사례만 2017년 7월 13 일 기준 21 례 발생하였다. 마지막 21번째 환자는 금년 6월 15일에 진 단되었고, 태국을 여행한 30대 여성이었다. 이로써 동남아에서 16 명, 중남미에서 5명이 감염되었으며, 필리핀이 8명으로 가장 많다. 연령대는 20대와 30대가 각각 7명으로 많았고, 여성도 7명 포함되었 으나 임신부는 없었다. 모든 환자는 가벼운 발열-발진성 질환의 경 과를 밝고 완전히 호전되었다 ${ }^{20)}$.

\section{선천 지카 증후군}

지카바이러스의 선천감염이 소두증을 비롯한 심각한 뇌기형을 포함하는 특징적인 선천성 기형을 초래한다는 보고들이 늘면서 결 국 선천 지카 증후군이라는 하나의 질환군으로 정의되기에 이르렀 다. 선천 지카 증후군에 속하는 대표적인 5 가지 임상양상은 Figure 1 과 같다 ${ }^{21)}$. 먼저 가장 특징적인 임상양상은 3 -표준편차 이하의 심 한 소두증을 동반하는 fetal brain disruption sequence (FBDS)이다. FBDS는 소두증과 머리뼈의 중첩, 해당 부위 피부의 과다, 심한 신경 학적 손상 등으로 발현하며, 이는 뇌 부피의 축소 및 이로 인한 두개 내 압력의 감소에 기인한다 ${ }^{22)}$. 다음은 뇌피질 하 석회화(subcortical calcification) 및 뇌피질의 두께 감소(thin cerebral cortices)이다. Cytomegalovirus (CMV) 선천 감염 시 나타나는 뇌영상 및 병리 소견 과 유사하나, $\mathrm{CMV}$ 감염 시에는 석회화가 주로 뇌실 주변으로 나타 나지만 선천 지카 증후군에서는 주로 피질 하 부위에 나타나는 것이 특징이다. 이러한 뇌 실질의 손상은 지카바이러스의 감염 자체 또는 지카바이러스 RNA에 의한 신경 세포의 손상과 관련 있는 것으로 생 각되고 있다 ${ }^{23)}$.

한편 선천 지카 증후군에서는 소안구증(microphalmia), 안조직 결손증(coloboma)과 같은 눈의 구조적 이상뿐 만 아니라, 백내장 (cataracts), 안구 내 석회화(intraocular calcifications), 시신경 위축/ 이상(optic nerve atrophy/anomaly), 맥락-망막 흥터(chorio-retinal scar) 등의 다양한 안과적 질환들이 24-55\%에서 동반되는 것으로 알 려져 있다. 특히 망막 병변 발생 시 황반(macula)까지 침범되는 것이 지카바이러스 감염의 특징적인 소견이다. 이러한 눈의 이상도 바이 러스의 직접 침범에 의한 세포 손상 또는 염증 반응에 의한 후유증으 로 생각되고 있다 ${ }^{24)}$.

다양한 신경 손상의 결과로 신체 여러 부위의 선천성 구축(congenital contracture)이 발생할 수 있다. 그 중 내반족(clubfoot)이 3.8$14 \%$ 로 가장 흔하며, 관절 만곡증(arthrogryposis)이 5.7-11\%로 다음 을 차지한다. 관절 만곡증이 있는 경우 고관절이나 무릎관절의 탈구 (dislocation)가 흔히 동반된다. 이러한 선천성 구축은 바이러스 감 염으로 인한 피질척수로(corticospinal tract) 및 말초/중추 운동 신

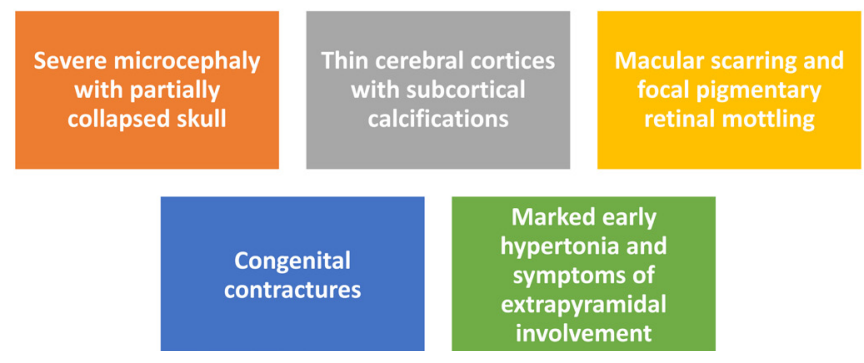

Figure 1. Clinical characteristics of congenital Zika syndrome. From Moore CA, et al. JAMA Pediatr 2017;171:288-95[21]. 
경의 손상이 태내의 움직임을 장기간 제한함으로써 발생하는 것으 로 추정된다 ${ }^{25}$. 다양한 신경학적 손상으로 인해 발달 장애, 경련, 삼 킴 장애, 청력 장애는 물론이고 자세 및 근 긴장 이상 등의 심각한 후 유증이 남게 된다. 특히 생후 초기에 진전(tremor)과 경직, 마비 등의 추체로(pyramidal)와 추체외로(extrapyramidal) 증상들을 보이는 것 이 선천 지카 증후군의 특징이다 ${ }^{26)}$.

\section{지카바이러스 선천 감염이 의심되는 신생아의 진단 및 관리}

지카바이러스 선천 감염의 진단은 우선 임신부 지카바이러스 감 염 의심환자로부터 시작된다. 일반 환자의 경우에는 발진과 함께 관 절통, 관절염, 근육통, 비화농성 결막염, 결막충혈 중 하나 이상이 동 반되면서 증상 시작 2주 이내에 역학적인 위험요인이 있을 때 검사 를 받도록 권고하고 있다 ${ }^{20)}$. 그러나 무증상 감염일 가능성과 선천 감염의 중요성을 고려하여 임신부에서는 발생국가 여행 등 위험 노 출력이 있고 본인이 검사를 원하며 의사가 필요하다고 판단하면 지 카바이러스에 대한 진단 검사 - 즉 분자생물학적 검사(real-time reverse transcription polymerase chain reaction, rRT-PCR)와 혈청학 적 검사(immunoglobulin $\mathrm{M}, \mathrm{IgM}$ )를 시행하게 된다 ${ }^{27)}$. 여기에서 양 성 판정을 받아서 지카바이러스 감염이 확인된 임신부로부터 태어 난 신생아에게는 선천 감염을 진단하기 위한 검사들을 시행하게 된 다(Figure 2$)^{28)}$. 그러나 유행 지역을 다녀온 지카바이러스 검사 음성 인 산모로부터 태어난 신생아가 소두증이나 두개 내 석회화 병변 등 선천 지카 증후군을 시사하는 임상적/신경방사선학적 소견을 보이 는 경우에도 신생아에게 지카바이러스 검사 및 임상평가가 요구된 다 $^{16)}$.

지카바이러스 감염을 확인하기 위해 신생아에서 혈관을 통해 직 접 채취한 혈청과 뇌척수액에서 rRT-PCR과 $\operatorname{IgM}$ 항체 검사를 하고, 소변에서 rRT-PCR검사를 시행한다. 여기에서 뇌척수액은 다른 목 적으로 채취한 경우에만 포함하는 것을 권고한다. 태반이나 제대, 또는 제대혈을 통한 rRT-PCR 또는 면역조직화학염색은 산모의 감염 과 선천감염을 구분할 수 없으므로 추천되지 않는다. 선천감염과 주 산기감염을 구분하기 위해 최초 검사는 가능하면 출생 후 2 일 이내 에 시행토록 권고한다. 혈청과 소변, 뇌척수액 중 어느 한 곳에서라 도 지카바이러스의 RNA가 rRT-PCR 검사 상 검출되면 지카바이러스 선천 감염으로 확진할 수 있다. rRT-PCR검사 상 음성이나, IgM이 양

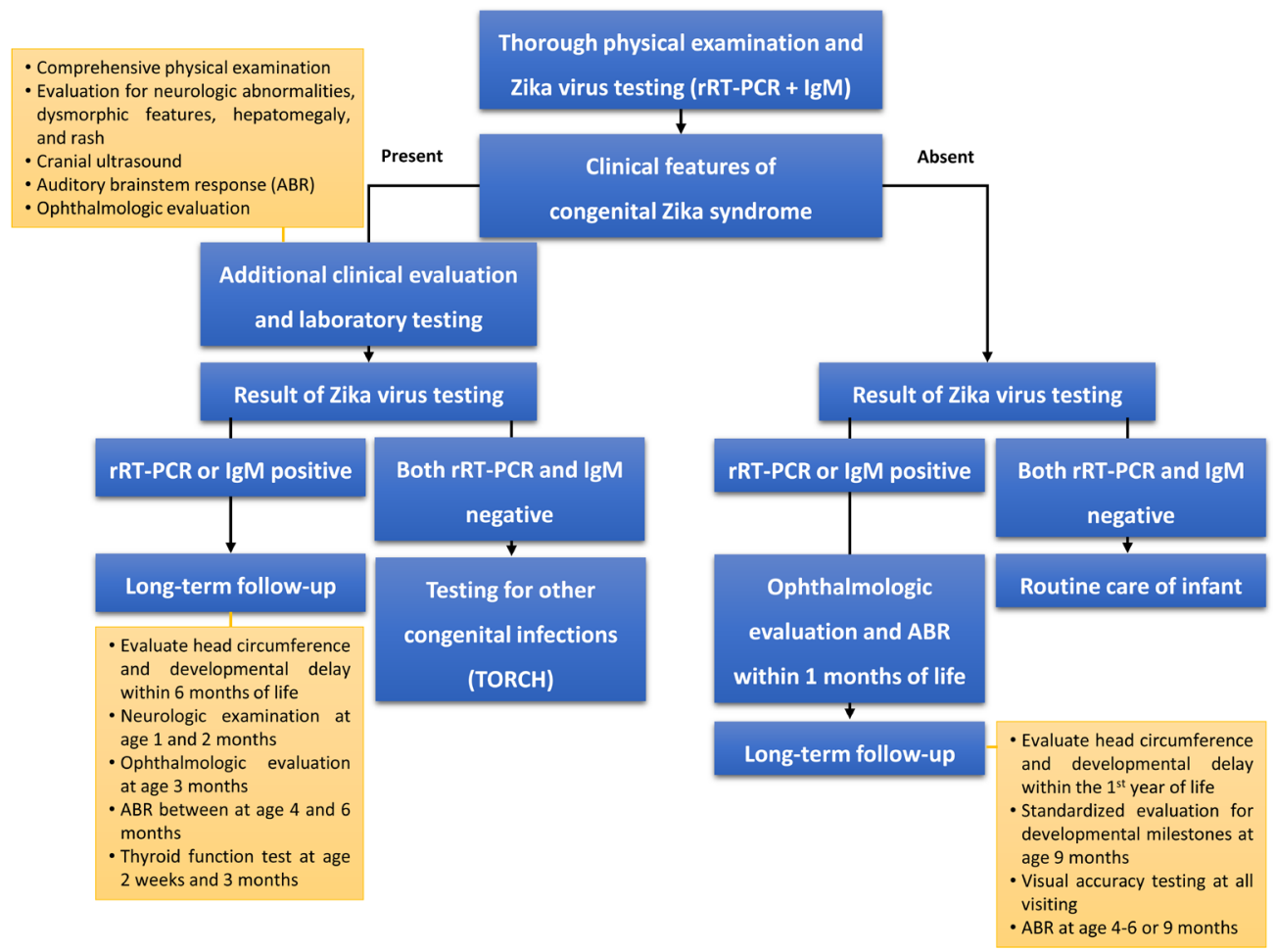

Figure 2. Guidance for evaluation and testing of neonates born to mothers with laboratory evidence of Zika virus infection during pregnancy. From Russell K, et al. MMWR Morb Mortal Wkly Rep 2016;65:870-8[28]. Abbreviations: rRT-PCR, real-time reverse transcription polymerase chain reaction; IgM, immunoglobulin $\mathrm{M}$; TORCH, toxoplasma, others, rubella virus, cytomegalovirus, herpes simplex virus. 
성인 경우 추정진단으로 간주하고 지카바이러스 중화항체 검사를 추가로 시행해야 한다. 그러나 2017년 7월 현재 국내에서는 해당 검 사가 준비되어 있지 않으므로, 이러한 경우 지카바이러스 선천 감염 에 준한 처치가 필요하다 ${ }^{20)}$. rRT-PCR과 IgM이 모두 음성인 경우 지 카바이러스 선천 감염을 배제할 수 있다.

지카바이러스 선천 감염의 가능성이 있는(임신 중 지카바이러스 감염이 검사로 확인된 산모에서 태어난) 신생아 및 영아에서는 지 카바이러스 진단 검사와 더불어 자세한 임상 평가가 필요하다. 머리 둘레, 키, 몸무게를 포함하는 충분한 신체 진찰과 특히 신경계 이상, 신체 변형(dysmorphic features), 간/비장 비대, 발진 등에 대한 평가 가 요구된다. 두부 초음파(head ultrasound) 검사를 시행하며, 청각 뇌간반응검사(auditory brainstem response, $\mathrm{ABR}$ ) 및 포괄적인 안과 검진이 퇴원 전 혹은 출생 후 1 개월 이내에 시행되어야 한다. 소두증 이나 두개 내 석회화가 있는 영아에서는 일반 혈액 검사와 간기능 검 사는 물론이고, 다른 선천감염에 대한 진단 검사를 시행하고, 필요 한 경우 뇌 영상촬영을 시행한다. 소두증은 출생 후 24시간 이내에 측정한 후두-전두부 둘레가 재태주령, 연령, 성별에 따른 표준 성장 곡선에서 2 백분위수 미만인 경우로 정의하지만, 선천 지카 증후군 에 대한 임상 평가가 필요한 경우는 3 백분위수 미만의 심한 소두증 을 동반한 경우로 권고하고 있다. 단, 머리 둘레가 3 백분위수 이상이 지만 키에 비해 뚜렷하게 작을 때, 중추신경계와 관련된 기능의 저하 를 가지고 있을 때에는 지카바이러스 감염에 대한 추가적인 평가를 고려한다 ${ }^{28)}$.

선천 지카 증후군으로 확진 된(검사 양성+뇌 기형) 영아에서는 생 후 6개월까지 성장/발달 사항 확인, 예방접종, 신체 기능 이상에 대 한 선제적 개입, 정서적 지지 등을 위해 매달 추적관찰이 필요하다. 생후 1 개월과 2 개월에는 각각 신경학적 검진을 시행하고, 생후 3 개 월에 포괄적인 안과 검진을, 생후 4-6개월에 두 번째 $\mathrm{ABR}$ 을 시행한 다. 생후 2 주와 3 개월에는 갑상선기능검사를 시행한다. 한편, 지카 바이러스 선천감염의 증거만 있는(선천 지카 증후군 아님) 영아에서 도 추가적인 추적관찰이 필요하다. 생후 9 개월에 표준화된 도구를 사용해서 발달을 평가하며, 외래 방문 시 마다 시력 검사를 시행한 다. 생후 4-6개월에 ABR 시행을 고려하고, 이 때 시행을 못 한 경우 에는 출생 직후 $\mathrm{ABR}$ 이 정상이었다면 생후 9 개월에 일반 청력 검사 를 시행한다 ${ }^{28)}$.

지카바이러스 선천감염의 치료제 및 예방 백신은 없다. 보존적으 로 치료하고, 개별적으로 발생한 임상적 문제에 대해 적절히 대처하 는 것이 최선이다. 산모의 감염을 막기 위해 최근 2 개월 이내에 지카 바이러스감염 환자가 발생한 국가로의 여행을 자제하고, 피치 못할 경우에는 모기에 물리지 않기 위해 권고되는 방법들을 적극적으로 시행토록 권고한다 ${ }^{29)}$.
결론

해외 여행 후 지카바이러스 감염사례는 꾸준히 발생하리라 추측 되며, 기온과 모기 서식지의 변화로 인해 국내 자체 발생도 가능하므 로 이 바이러스에 의한 가장 중요한 임상 양상인 선천 지카 증후군의 진단 및 관리에 있어서 최신 지견을 유지하는 것이 중요하다. 유행 지역을 다녀온 임신부로부터 태어난 신생아뿐 만 아니라 특별한 노 출력 없이 태어난 신생아에서도 그 특징적인 임상 양상으로부터 선 천 지카 증후군을 의심하고 적절히 진단하여 다학제적 중재를 조기 에 시행해야 한다. 이를 통해 해당 환자의 장기 예후를 크게 향상시 킬 수 있을 것이다.

\section{REFERENCES}

1) Fauci AS, Morens DM. Zika virus in the Americas--yet another arbovirus threat. N Engl J Med 2016;374:601-4.

2) Mlakar J, Korva M, Tul N, Popovic M, Poljsak-Prijatelj M, Mraz J, et al. Zika virus associated with microcephaly. $\mathrm{N}$ Engl J Med 2016;374:951-8.

3) Lim SK, Lim JK, Yoon IK. An update on zika virus in asia. Infect Chemother 2017;49:91-100.

4) Weaver SC, Barrett AD. Transmission cycles, host range, evolution and emergence of arboviral disease. Nat Rev Microbiol 2004;2:789-801.

5) Rubin EJ, Greene MF, Baden LR. Zika virus and microcephaly. N Engl J Med 2016;374:984-5.

6) Boorman JP, Porterfield JS. A simple technique for infection of mosquitoes with viruses; transmission of Zika virus. Trans $R$ Soc Trop Med Hyg 1956;50:238-42.

7) Ciota AT, Bialosuknia SM, Zink SD, Brecher M, Ehrbar DJ, Morrissette MN, et al. Effects of Zika virus strain and aedes mosquito species on vector competence. Emerg Infect Dis 2017;23: 1110-7.

8) Paupy C, Delatte H, Bagny L, Corbel V, Fontenille D. Aedes albopictus, an arbovirus vector: from the darkness to the light. Microbes Infect 2009;11:1177-85.

9) Bonizzoni M, Gasperi G, Chen X, James AA. The invasive mosquito species Aedes albopictus: current knowledge and future perspectives. Trends Parasitol 2013;29:460-8.

10) Hayes EB. Zika virus outside Africa. Emerg Infect Dis 2009; 15:1347-50.

11) Musso D, Gubler DJ. Zika virus. Clin Microbiol Rev 2016;29:487524.

12) Cao-Lormeau VM, Blake A, Mons S, Lastere S, Roche C, Vanhomwegen J, et al. Guillain-Barre Syndrome outbreak associated with Zika virus infection in French Polynesia: a case- 
control study. Lancet 2016;387:1531-9.

13) Rasmussen SA, Jamieson DJ, Honein MA, Petersen LR. Zika virus and birth defects--reviewing the evidence for causality. $\mathrm{N}$ Engl J Med 2016;374:1981-7.

14) Yun KW. Zika virus infection: perspectives as a specialist of pediatric infectious diseases. Pediatr Infect Vaccine 2016;23:1-9.

15) Cunha AJ, de Magalhaes-Barbosa MC, Lima-Setta F, Medronho RA, Prata-Barbosa A. Microcephaly case fatality rate associated with zika virus infection in brazil: current estimates. Pediatr Infect Dis J 2017;36:528-30.

16) Reynolds MR, Jones AM, Petersen EE, Lee EH, Rice ME, Bingham $\mathrm{A}$, et al. Vital signs: update on zika virus-associated birth defects and evaluation of all U.S. infants with congenital Zika virus exposure - U.S. Zika pregnancy registry, 2016. MMWR Morb Mortal Wkly Rep 2017;66:366-73.

17) Duffy MR, Chen TH, Hancock WT, Powers AM, Kool JL, Lan ciotti RS, et al. Zika virus outbreak on Yap Island, Federated States of Micronesia. N Engl J Med 2009;360:2536-43.

18) Cao-Lormeau VM, Roche C, Teissier A, Robin E, Berry AL, Mallet HP, et al. Zika virus, French polynesia, South pacific, 2013. Emerg Infect Dis 2014;20:1085-6.

19) World Health Organization. Zika situation report [Internet]. World Health Organization; 2017 [cited 2017 Jul 13]. Available from: http://www.who.int/emergencies/zika-virus/situationreport/10-march-2017/en.

20) Korean Centers for Disease Control and Prevention. Zika virus update [Internet]. Korean Centers for Disease Control and Prevention; 2017 [cited 2017 Jul 13]. Available from: http:// www.http://cdc.go.kr/CDC/health/CdcKrHealth0101.jsp? menuIds =HOME001-MNU1132-MNU1147-MNU0746-MNU 2423\&fid $=7956 \&$ cid $=68928$.

21) Moore CA, Staples JE, Dobyns WB, Pessoa A, Ventura CV, Fonseca EB, et al. Characterizing the pattern of anomalies in congenital Zika syndrome for pediatric clinicians. JAMA pediatr 2017;171:288-95.
22) Moura da Silva AA, Ganz JS, Sousa PD, Doriqui MJ, Ribeiro MR, Branco MD, et al. Early growth and neurologic outcomes of infants with probable congenital Zika virus syndrome. Emerg Infect Dis 2016;22:1953-6.

23) Driggers RW, Ho CY, Korhonen EM, Kuivanen S, Jaaskelainen AJ, Smura T, et al. Zika virus infection with prolonged maternal viremia and fetal brain abnormalities. N Engl J Med 2016; 374:2142-51.

24) de Paula Freitas B, de Oliveira Dias JR, Prazeres J, Sacramento GA, Ko AI, Maia M, et al. Ocular findings in infants with microcephaly associated with presumed Zika virus congenital infection in Salvador, Brazil. JAMA ophthalmol 2016 Feb 9. doi: 10.1001/jamaophthalmol.2016.0267.

25) van der Linden V, Filho EL, Lins OG, van der Linden A, Aragao Mde F, Brainer-Lima AM, et al. Congenital Zika syndrome with arthrogryposis: retrospective case series study. BMJ 2016; 354:i3899.

26) Culjat M, Darling SE, Nerurkar VR, Ching N, Kumar M, Min SK, et al. Clinical and imaging findings in an infant with Zika embryopathy. Clin Infect Dis 2016;63:805-11.

27) Petersen EE, Polen KN, Meaney-Delman D, Ellington SR, Oduyebo T, Cohn A, et al. Update: interim guidance for health care providers caring for women of reproductive age with possible Zika virus exposure--United States, 2016. MMWR Morb Mortal Wkly Rep 2016;65:315-22.

28) Russell K, Oliver SE, Lewis L, Barfield WD, Cragan J, MeaneyDelman D, et al. Update: interim guidance for the evaluation and management of infants with possible congenital Zika virus infection - United States, August 2016. MMWR Morb Mortal Wkly Rep 2016;65:870-8.

29) D'Angelo DV, Salvesen von Essen B, Lamias MJ, Shulman $H$, Hernandez-Virella WI, Taraporewalla AJ, et al. Measures taken to prevent Zika virus infection during pregnancy - Puerto Rico, 2016. MMWR Morb Mortal Wkly Rep 2017;66:574-8. 